\title{
CHANGES IN HEALTH BEHAVIOUR AND EMOTIONAL WELL-BEING OF PREGNANT WOMEN DURING THE COVID-19 PANDEMIC IN LATVIA
}

\author{
Roberta Rezgale ${ }^{1, \#}$, Vinita Cauce ${ }^{1}$, Violeta Bule ${ }^{1,3}$, Anna Piskurjova ${ }^{1}$, \\ and Laila Meija ${ }^{1,2}$ \\ Rīga Stradiṇ̌̌ University, 16 Dzirciema Str., Rīga, LV-1007, LATVIA \\ Pauls Stradinš Clinical University Hospital, 13 Str., Rīga, LV-1002, LATVIA \\ Rīga East Clinical University Hospital, 2 Hipokrāta Str., Rīga, LV-1038, LATVIA \\ \# Corresponding author, roberta.rezgale@rsu.Iv
}

Communicated by Mārcis Leja

\begin{abstract}
Pregnancy is a vulnerable period of life for changes in physical and mental health, which could be exacerbated by COVID-19. The aim of this study was to assess the impact of COVID-19 on health behaviour and emotional well-being among pregnant women in Latvia. The cross-sectional study included 269 women: pregnant women in the third trimester and women until the $7^{\text {th }}$ day post-partum. The study was conducted between July and October 2020, performed by a trained interviewer. Information regarding demographic, anthropometric data, self-assessment of changes in nutritional habits, daily physical activities, and emotional well-being due to the COVID-19 pandemic was collected. $31.6 \%$ reported cooking at home more often and only $10.4 \%$ reported eating more often and/or larger portions, 23.2\% were going on walks outdoors more often, $32.9 \%$ were feeling anxious, insecure about health of themselves and relatives, and $24.8 \%$ were lacking communication with friends and family. Latvian women were emotionally more affected than other nationalities $(\mathrm{p}=0.015)$. Overall, women $30+$ years of age were more often affected then women aged up to 30 years $(\mathrm{p}=0.014)$. These results suggest that the COVID-19 pandemic had notable impact on health behaviour and emotional well-being in pregnant women in Latvia, especially on women 30+ years of age, who may need more careful counselling.
\end{abstract}

Keywords: post-partum, pregnancy, diet, physical activity, emotional response.

\section{INTRODUCTION}

Health behaviour, including eating, physical activity, and emotional well-being of pregnant women has a large impact on maternal and foetal health as well as pregnancy outcome (Grote et al., 2010; Koletzko et al., 2018). Pregnancy is a time of foetal growth and maternal physiological changes that require adequate dietary macronutrient and micronutrient intake. Data suggest that an inadequate diet during pregnancy increases the risk of developing a number of maternal pathologies such as gestational diabetes, preeclampsia as well as foetal macrosomia, premature birth, and increases an offspring's risk of developing non-communicable diseases later in life (Ho et al., 2016). Evidence supports the beneficial effect of regular physical activity during pregnancy, by maintaining and improving physical and mental health, and preventing excessive gestational weight gain and gestational diabetes, relieving some of the discomforts of pregnancy (Nascimento et al., 2012). Additionally, prenatal exercise reduces the odds of prenatal depression (Davenport et al., 2018). Despite the proven benefits of physical activities, there is evidence that suggests decrease in physical activity during pregnancy (Fell et al., 2009; Abbasi and van den Akker, 2015).

Available data indicate that approximately $12 \%$ of women experience depression and $13 \%$ anxiety at some point in pregnancy, and many women experience both (Rees et al., 2019). Data show that prenatal depression and anxiety have adverse effect on an offspring's socio-emotional development and behavioural functioning (Madigan et al, 2018) and 
in addition, psychosocial stress is a risk factor of preterm birth (Shapiro et al., 2013).

On 11 March 2020, the World Health Organisation (WHO) declared COVID-19 a pandemic. Consequently, there were increases in fear of contamination with the virus, and fear for the health of loved ones (Mertens et al., 2020). Furthermore, countries around the globe implemented many restrictions to slow the spread of the virus. These included social and physical distancing, working from home, closure of schools, universities, gyms, sports centres, restaurants, cafeterias, and termination of non-essential services. As a result, the everyday lives, employment, and communication opportunities of the population, including of pregnant women, were disturbed. The possible limitations in accessibility of food, job losses, reduced income, and uncertainty of the future, raised concern for the negative changes in health behaviour that could occur during the pandemic. Evidence from many countries already suggests that the pandemic together with initiatives taken by governments have adverse effects on dietary patterns, physical activity and emotional well-being in adults (Brooks et al., 2020; Scarmozzino et al., 2020). For $15.3 \%$ of more than 1000 responders in Latvia, COVID-19 restrictions caused increased worries not to have enough food and $12.2 \%$ noted a decrease in the ability to eat preferred food; however, almost one-fifth of responders increased consumption of foods of low nutritional value, especially among 25-39 old ones and in households where the economic situation became worse (Pitkevica et al., 2021).

Seeing that during pregnancy women already go through mental as well as physical changes, additional stressors caused by the pandemic, such as having to change birth plans, families not being able to be present during birth, and worries about families being infected, may mean that pregnant women are more vulnerable to adverse health behaviour changes (Fakari et al., 2020).

It is especially important to recognise the impact of the COVID-19 pandemic on the health behaviour and emotional well-being in pregnant women to prevent adverse health outcomes for both the mother and offspring.

The aim of this study was to evaluate the impact of the COVID-19 pandemic on the health behaviour and emotional well-being in pregnant women in Latvia.

\section{MATERIALS AND METHODS}

The presented data are part of the project "Excess Weight, Dietary Habits and Vitamin D and Omega-3 Fatty Acid Status in Pregnancy" (No. lzp-2019/1-0335 funded by the Latvian Council of Science).

A cross-sectional study including pregnant women in the third trimester and women until the $7^{\text {th }}$ day post-partum was conducted between July and October 2020 ( $n=269$ ). This period in Latvia was characterised by a number of restrictions. Face-to-face interviews were held in maternity outpa- tient clinics and maternity hospitals in various regions of Latvia. Exclusion criteria were: age less than 18 years; multiple pregnancies; place of residence outside Latvia during pregnancy; history of or present health disorders - diabetes, celiac disease, short bowel syndrome, Crohn's disease, ulcerative colitis; and history of eating disorders.

The study procedure was approved by the Ethics Committee of Rīga Stradiňš University (Ref. No: 6 -1/02/62). Written informed consent was obtained from all participants prior to the study. Participants were provided with written information about the aim and purpose of the study. The study was anonymous as questionnaires were marked with code numbers only.

Data were obtained using a self-developed questionnaire. Survey was performed by a trained interviewer. The questionnaire consisted of the following parts: demographic data, anthropometric data, self-assessment of nutritional habits, daily physical activities and emotional well-being.

Change in dietary patterns was assessed by asking "How has the COVID-19 pandemic influenced your dietary habits?". Response options were: (1) no influence; (2) eating healthier, paying more attention to the quality and composition of food; (3) eating less healthy; (4) eating more often and/or larger portions; (5) eating less often and/or smaller portions; (6) spending less money on food; and (7) cooking at home more often.

Change in the physical activity behaviour was assessed by asking "How has the COVID-19 pandemic influenced your everyday physical activities?". Response options were: (1) no influence, continuing doing physical activities; (2) no influence, have not started physical activities; (3) going on walks outdoors more often; (4) have started doing physical activities because did not have time before; (5) have changed the type/location of physical activities (exercising at home/outdoors); (6) have increased the intensity of physical activities; and (7) decreased, spending more time at home/indoors.

Change in emotional well-being was assessed by asking "How has the COVID-19 pandemic influenced your everyday emotional well-being?" Response options were: (1) no influence, feeling calm and safe; (2) feeling anxious, insecure about health of myself and relatives; (3) lacking communication with friends and family; (4) feeling sad, lacking emotional support; (5) having sleep disturbances; (6) fearing the unknown future; (7) feeling more easily irritated; and (8) having more family disagreements.

Body mass index (BMI) was classified according to the World Health Organisation recommendations (WHO, 1995).

Data cleaning was performed focusing on: accuracy of data entries and identification of missing data. The continuous variables were described as the means (SD), and categorical variables were described as numbers (percentages). The influence of the COVID-19 pandemic was evaluated if re- 
spondents reported influence or no influence in questions on dietary patterns, physical activity behaviours, and emotional well-being. The associations between influence of the COVID-19 pandemic and demographic parameters were analysed using the Chi-square test, with a $p$ value of $<0.05$ indicating statistical significance. Data were analysed using IBM SPSS 26.0.

\section{RESULTS}

Demographic characteristics. A total of 269 women were included in this study, $22(8.2 \%)$ pregnant women and 247 $(91.8 \%)$ women until the $7^{\text {th }}$ day post-partum. Most of the health professionals providing maternal health care $(\mathrm{n}=$ 236; $91.1 \%$ ) were obstetricians and gynaecologists. Mean age of participants included in the study was 31.2 (SD 5.4) years. Interviews took place in Rīga and suburbs of Rīga $(\mathrm{n}=181 ; 67.3 \%)$ and in other regions of Latvia $(\mathrm{n}=88$; $32.7 \%$ ). The general characteristics of the study sample are included in Table 1.

Changes in dietary patterns. Figure 1 shows the selfreported changes in dietary patterns during the COVID-19 pandemic. The majority of participants $(n=168 ; 62.5 \%)$ reported no changes in dietary habits, almost one-third ( $\mathrm{n}=$ $85(31.6 \%)$ ) reported cooking at home more often, and only $21(10.4 \%)$ reported eating more often and/or larger portions.

Statistically significant differences of changes in dietary patterns during the COVID-19 pandemic were found:

- between age groups: women $30+$ years of age were affected more often $(\mathrm{n}=80 ; 46.5 \%)$ than younger women (aged till 30 years) $(n=21 ; 21.6 \%)(p<0.001)$; the majority of women $30+$ years of age reported spending less money on food and more often cooking at home;

- between BMI categories before pregnancy: women with $\mathrm{BMI}<25 \mathrm{~kg} / \mathrm{m}^{2}$ were more affected $(\mathrm{n}=82 ; 42.3 \%)$ than those with BMI $\geq 25 \mathrm{~kg} / \mathrm{m}^{2}(\mathrm{n}=18 ; 25.7 \%)(p=0.014)$. Women with BMI $<25 \mathrm{~kg} / \mathrm{m}^{2}$ reported eating unhealthier and eating more often and/or larger portions;

- among different levels of education: women with higher education were more affected $(n=71 ; 44.4 \%)$ than those with the basic education $(\mathrm{n}=4 ; 15.4 \%)(p=0.018)$. Women with higher education reported spending less money on food and cooking at home more often.

No statistically significant difference was found regarding the change of dietary patterns among different nationalities, marital status and the number of births.

Changes in physical activity behaviour. Figure 2 shows the self-reported changes in physical activity behaviour during the COVID-19 pandemic. The majority of women $(\mathrm{n}=$ $163 ; 61.9 \%$ ) did not change patterns of physical activity: more than one-third $(\mathrm{n}=99 ; 37.6 \%)$ continued doing physical activities and around one quarter $(n=64 ; 24.3 \%)$ did not
Table 1. General characteristics of participants

\begin{tabular}{lc}
\hline \multicolumn{1}{c|}{ Characteristics } & $\mathrm{n}(\%)$ \\
\hline Age (years) & $97(36.1)$ \\
$<30$ & $172(63.9)$ \\
$30+$ & \\
Nationality & $203(75.5)$ \\
$\quad$ Latvian & $66(24.5)$ \\
Other & \\
Body mass index* $\left(\mathrm{kg} / \mathrm{m}^{2}\right)$ & $194(73.5)$ \\
$<25$ & $70(26.5)$ \\
$25+$ & \\
Education & $26(9.7)$ \\
Basic (primary) & $63(23.4)$ \\
General/vocational secondary & $20(7.4)$ \\
College, unfinished higher & $160(59.5)$ \\
Higher & \\
Marital status & $260(96.7)$ \\
Married or cohabitation & $9(3.3)$ \\
Single & $116(43.1)$ \\
Number of births & $153(56.9)$ \\
First &
\end{tabular}

* before pregnancy, missing 5

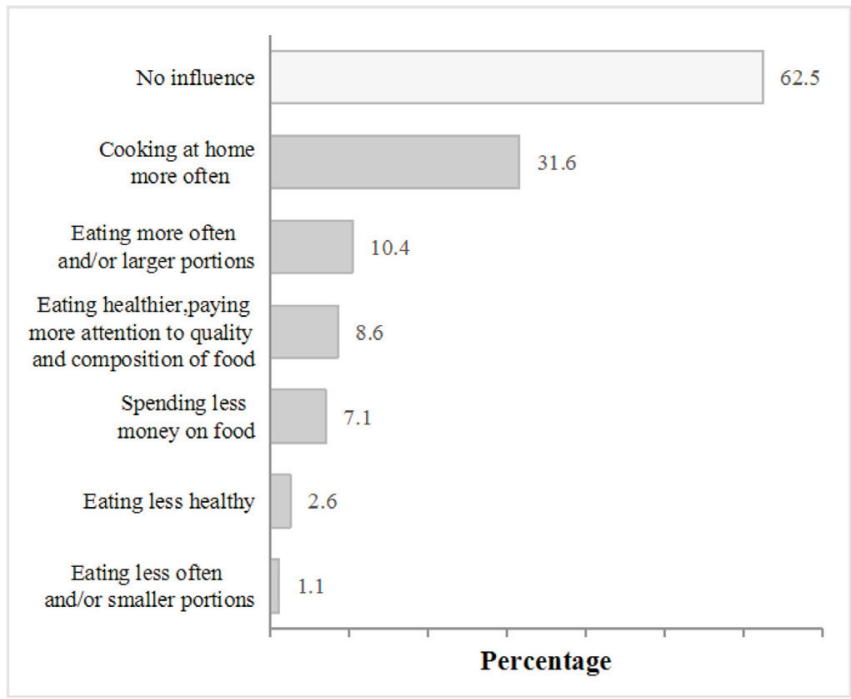

Fig. 1. Self-perception of changes in dietary patterns during the COVID-19 pandemic $(\%)$.

start physical activities. However, 61 women (23.2\%) were more often going on walks outdoors.

Statistically significant differences of changes in physical activity behaviour during the COVID-19 pandemic were found between age groups: women $30+$ years of age were affected more often $(\mathrm{n}=84 ; 48.8 \%)$ than younger women (aged till 30 years) $(n=32 ; 33.0 \%)(p=0.012)$; women $30+$ years of age increased intensity of physical activities and went on walks outdoors more often.

No statistically significant difference was found regarding the change of physical activity among different nationali- 


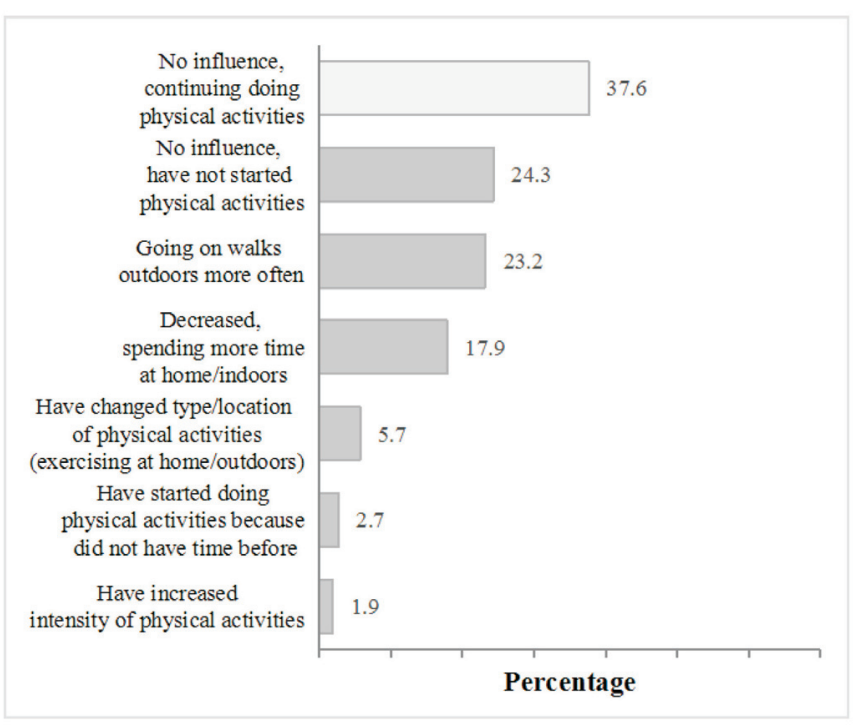

Fig. 2. Self-perception of changes in physical activity behaviour during the COVID-19 pandemic (\%).

ties, marital status, educational level, BMI categories, and the number of births.

Changes in emotional well-being. Figure 3 shows the self-reported changes in emotional well-being. More than a half of the women $(n=139 ; 56.5 \%)$ reported no influence of the COVID-19 pandemic, were feeling calm and safe, whereas almost one-third $(\mathrm{n}=81 ; 32.9 \%)$ were feeling anxious, insecure about health of themselves and relatives and almost a quarter $(\mathrm{n}=61 ; 24.8 \%)$ were lacking communication with friends and family.

Statistically significant differences of changes of emotional well-being during the COVID19 pandemic were found between:

- pregnant woman (22) who were not affected and women until the $7^{\text {th }}$ day post-partum $(\mathrm{n}=116 ; 47.0 \%)$ who were affected $(p<0.001)$

- nationalities: Latvian women were more affected ( $n=96$; $47.3 \%)$ than the one of the other nationalities $(n=20$; $30.3 \%)(p=0.015)$. Latvian women more often were afraid about the unknown future and felt sad, lacked emotional support, and communication;

- educational levels: women with general/vocational secondary education and higher education were emotionally rather affected ( $n=49.2 \%$ and $46.9 \%$, respectively), while women with college education were the least affected $(\mathrm{n}=2 ; 10.0 \%)(p=0.006)$. Women with general/vocational secondary education had sleep disturbances more often and felt more easily irritated.

No statistically significant difference was found between age groups and BMI categories.

Overall, only 86 (32\%) women reported no influence of the COVID-19 pandemic during pregnancy, neither on their dietary patterns, nor physical activity and emotional well-

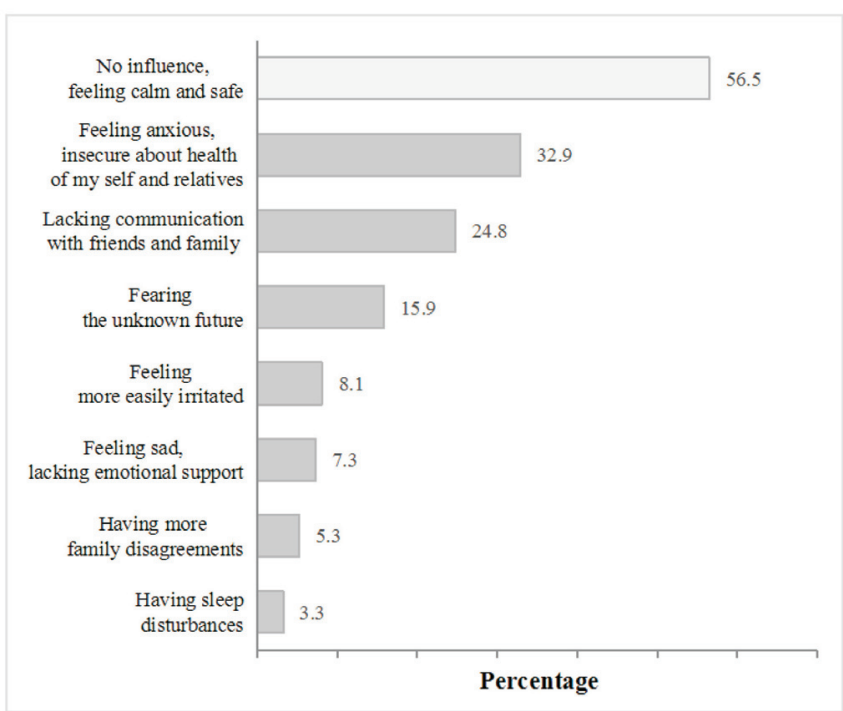

Fig. 3. Self-perception of changes of emotional well-being during the COVID-19 pandemic (\%)

being. In contrast $183(68 \%)$ perceived some influence of the COVID-19 pandemic to at least of one of previously mentioned parameters. Analysing overall changes, statistically significant differences of changes during the COVID19 pandemic were found between age groups: women $30+$ years of age were more often $(n=126(73.3 \%))$ affected then younger women aged till 30 years $(\mathrm{n}=57 ; 58.8 \%))$ ( $p=0.014)$; no statistically significant differences were found in other parameters (nationality, education, marital status, BMI categories).

\section{DISCUSSION}

In the present study, we evaluated changes in the health behaviour and emotional well-being in pregnant women in Latvia due to the COVID-19 pandemic and determined whether sociodemographic and clinical parameters were associated with these changes. Overall, two-thirds of women confirmed the influence of COVID-19 to at least one factor. From 13 March 2020 to 6 June 2020, the government of Latvia announced an emergency situation with a full lockdown. Schools were closed, everyone who was able to had to work from home. All gyms were closed. From June until about the middle of September, the spread of COVID-19 was under control, and therefore, very few social isolation rules were in place. Regarding opportunities for physical exercise, most gyms were open in limited capacity. However, from the middle of September, regulations were similar as in March-June; this could mean that the participants interviewed in the summer were less impacted by the pandemic than those interviewed in the fall. During the time with the most restrictions, it was not possible to interview the participants.

Changes in dietary patterns during the COVID-19 pandemic could be caused by possible changes in purchasing food, with people having to spend more time at home. There are 
published data showing changes in dietary habits in some population groups, for example, increased cooking at home (Flanagan et al., 2021), which is consistent with our data. This finding is likely due to the limitations of eating outside of home and the costly food delivery service. The results of a study on lifestyle behaviour changes among pregnant women in the U.S. showed that $17 \%$ reported having a worse diet and $42 \%$ reported having an improved diet during the COVID-19 pandemic (Whitaker et al., 2021). Our data show similar diverse results, as $10.4 \%$ of women reported eating more often and/or larger portions, which could be as a consequence of working from home and having constant access to food, while $8.6 \%$ reported eating healthier, paying more attention to quality and composition of food, perhaps due to having more time for cooking and increased health consciousness during the pandemic. However, there are studies conducted in different countries that report healthier dietary habits in adults during the COVID-19 pandemic (Rodríguez-Pérez et al., 2020; Wang et al., 2020). Moreover, there are data on UK adults showing associations between higher BMI and lower diet quality and increased overeating (Robinson et al., 2021). In this study, we did not find such association, possibly because the majority of women had normal pre-pregnancy BMI.

Studies in pregnant populations suggest decreased levels of physical activity during COVID-19 restrictions (Biviá-Roig et al., 2020; Whitaker et al., 2021), and these results concur with findings from studies in non-pregnant populations, which show a decrease in physical activity during the COVID-19 pandemic (Ammar et al., 2020; Tison et al., 2020; Flanagan et al., 2021). Our data suggest that although the majority of women $(61.9 \%)$ did not change physical activity behaviour, $23.2 \%$ went on walks outdoors more often. This could be because of the government advising and social media inspiring going outdoors as an alternative to all the activities that were restricted. Women $30+$ years of age went for walks outdoors more than younger women, possibly due to stronger sense of responsibility.

Pregnant women have elevated risk for mental health difficulties compared to the general public, which are likely to be exacerbated by the COVID-19 pandemic (Gildner et al., 2020; Khoury et al., 2021). There are published studies that examined the impact of the COVID-19 pandemic on maternal stress and anxiety, which found that average anxiety and stress scores increased between $26.13 \%$ and $58.82 \%$ (Quistorff et al., 2021). Our findings indicate that almost onethird were feeling anxious, insecure about health of themselves and relatives, corroborating the aforementioned results. In addition, almost one-fourth of the women were lacking communication, with Latvian women being more affected than other nationalities, perhaps attributable to the different mentalities with Latvian women being emotionally more closed than other nationality women living in Latvia. The emotional well-being was most affected in women with general/vocational secondary education, while women with college education were the least affected, which could be due to different sources of information in these two groups.
One of the strengths of this study is that data was collected by trained interviewers and it was done in maternity departments; therefore, it is likely that a more diverse group of women were involved, including those who would not have participated in online surveys.

The sample group of pregnant women were from all regions of Latvia, different ages, with education levels, and different pre-pregnancy BMI categories. However, the sample size was not representative, because the interviews were discontinued during the exacerbation of the COVID-19 pandemic. The limitation of the present study is self-reported data of dietary patterns, physical activity, and emotional well-being, which could be prone to bias.

\section{CONCLUSION}

In conclusion, our findings suggest that the COVID-19 pandemic adversely impacted health behaviour and emotional well-being in pregnant women in Latvia, especially pregnant women $30+$ years of age. The defined groups may require more careful counselling on health behaviour during pregnancy and after giving birth.

\section{ACKNOWLEDGEMENTS}

We thank Livva Ušpele for her invaluable help with study design and data collection.

This study was done within the frame of the project No. lzp-2019/1-0335 funded by the Latvian Council of Science.

\section{REFERENCES}

Abbasi, M., Akker, O. van den (2015). A systematic review of changes in women's physical activity before and during pregnancy and the postnatal period. J. Reprod. Infant Psychol., 33 (4), 325-358.

Ammar, A., Brach, M., Trabelsi, K., Chtourou, H., Boukhris, O., Masmoudi, L., Bouaziz, B., Bentlage, E., How, D., Ahmed, M., et al. (2020). Effects of COVID-19 home confinement on eating behaviour and physical activity: Results of the ECLB-COVID19 international online survey. Nutrients, 12 (6), 1583 .

Biviá-Roig, G., La Rosa, V. L., Gómez-Tébar, M., Serrano-Raya, L., AmerCuenca, J. J., Caruso, S., Commodari, E., Barrasa-Shaw, A., Lisón, J. F. (2020). Analysis of the impact of the confinement resulting from COVID-19 on the lifestyle and psychological wellbeing of Spanish pregnant women: an Internet-based cross-sectional survey. Int. J. Environ. Res. Publ. Health, 17 (16), 5933.

Brooks, S. K., Webster, R. K., Smith, L. E., Woodland, L., Wessely, S., Greenberg, N., Rubin, G. J. (2020). The psychological impact of quarantine and how to reduce it: Rapid review of the evidence. The Lancet, 395 (10227), 912-920.

Davenport, M. H., McCurdy, A. P., Mottola, M. F., Skow, R. J., Meah, V. L., Poitras, V. J., Garcia, A. J., Gray, C. E., Barrowman, N., Riske, L., et al. (2018). Impact of prenatal exercise on both prenatal and postnatal anxiety and depressive symptoms: A systematic review and meta-analysis. Brit. J. Sports Med., 52 (21), 1376-1385.

Fakari, F. R., Simbar, M. (2020). Coronavirus pandemic and worries during pregnancy: A letter to editor. Arch. Acad. Emerg. Med., 8 (1), e21-e21.

Fell, D. B., Joseph, K. S., Armson, B. A., Dodds, L. (2009). The impact of pregnancy on physical activity level. Maternal Child Health J., 13 (5), 597. 
Flanagan, E. W., Beyl, R. A., Fearnbach, S. N., Altazan, A. D., Martin, C. K., Redman, L. M. (2021). The impact of COVID-19 stay-at-home orders on health behaviors in adults. Obesity, 29 (2), 438-445.

Gildner, T. E., Laugier, E. J., Thayer, Z. M. (2020). Exercise routine change is associated with prenatal depression scores during the COVID-19 pandemic among pregnant women across the United States. PloS One, 15 (12), $\mathrm{e} 0243188$.

Grote, N. K., Bridge, J. A., Gavin, A. R., Melville, J. L., Iyengar, S., Katon, W. J. (2010). A meta-analysis of depression during pregnancy and the risk of preterm birth, low birth weight, and intrauterine growth restriction. Arch. Gen. Psychiatry, 67 (10), 1012-1024.

Ho, A., Flynn, A. C., Pasupathy, D. (2016). Nutrition in pregnancy. Obstetrics Gynaecol. Reprod. Med., 26 (9), 259-264.

Khoury, J. E., Atkinson, L., Bennett, T., Jack, S. M., Gonzalez, A. (2021). COVID-19 and mental health during pregnancy: The importance of cognitive appraisal and social support. J. Affect. Disord., 282, 1161-1169.

Koletzko, B., Cremer, M., Flothkötter, M., Graf, C., Hauner, H., Hellmers, C., Kersting, M., Krawinkel, M., Przyrembel, H., Röbl-Mathieu, M., Schiffner, U., Vetter, K., Weißenborn, A., Woeckel, A. (2018). Diet and lifestyle before and during pregnancy: Practical recommendations of the Germany-wide healthy start-young family network. Geburtshilfe und Frauenheilkunde, 78 (12), 1262.

Madigan, S., Oatley, H., Racine, N., Fearon, R. P., Schumacher, L., Akbari, E., Cooke, J. E., Tarabulsy, G. M. (2018). A meta-analysis of maternal prenatal depression and anxiety on child socioemotional development. $J$. Amer. Acad. Child Adolesc. Psychiatry, 57 (9), 645-657.

Mertens, G., Gerritsen, L., Duijndam, S., Salemink, E., Engelhard, I. M. (2020). Fear of the coronavirus (COVID-19): Predictors in an online study conducted in March 2020. J. Anxiety Disord., 74, 102258.

Nascimento, S. L., Surita, F. G., Cecatti, J. G. (2012). Physical exercise during pregnancy: A systematic review. Curr. Opin. Obstetr. Gynecol., 24 (6), 387-394.

Pitkēviča, I., Pumpure, E., Graviṇa, M. L., Mihailova, D., Briedīte, I., Rezeberga, D., Kantāne, I., Kīivīte-Urtāne, A., Lazdāne, G. (2022). Socioeconomic factors and changes in food choice and availability during
COVID-19 restrictions in Latvia. Proc. Latvian Acad. Sci., Section B, 76 (1), 36-41 (this issue).

Quistorff, J. L., Saeed, H., Lopez, C., Andescavage, N. N., Limperopoulos, C. (2021). 938 Pregnancy and COVID-19: The impact on maternal mental health. Amer. J. Obstetr. Gynecol., 224 (2), S582.

Rees, S., Channon, S., Waters, C. S. (2019). The impact of maternal prenatal and postnatal anxiety on children's emotional problems: A systematic review. Eur. Child Adolesc. Psychiatry, 28 (2), 257-280.

Robinson, E., Boyland, E., Chisholm, A., Harrold, J., Maloney, N. G., Marty, L., Mead, B. R., Noonan, R., Hardman, C. A. (2021). Obesity, eating behavior and physical activity during COVID-19 lockdown: A study of UK adults. Appetite, 156, 104853.

Rodríguez-Pérez, C., Molina-Montes, E., Verardo, V., Artacho, R., García-Villanova, B., Guerra-Hernández, E. J., Ruíz-López, M. D. (2020). Changes in dietary behaviours during the COVID-19 outbreak confinement in the Spanish COVIDiet study. Nutrients, 12 (6), 1730.

Scarmozzino, F., Visioli, F. (2020). Covid-19 and the subsequent lockdown modified dietary habits of almost half the population in an Italian sample. Foods, 9 (5), 675.

Shapiro, G. D., Fraser, W. D., Frasch, M. G., Séguin, J. R. (2013). Psychosocial stress in pregnancy and preterm birth: Associations and mechanisms. J. Perinatal Med., 41 (6), 631-645.

Tison, G. H., Avram, R., Kuhar, P., Abreau, S., Marcus, G. M., Pletcher, M. J., Olgin, J. E. (2020). Worldwide effect of COVID-19 on physical activity: A descriptive study. Ann. Int. Med., 173 (9), 767-770.

Wang, X., Lei, S. M., Le, S., Yang, Y., Zhang, B., Yao, W., Gao, Z., Cheng, S. (2020). Bidirectional influence of the COVID-19 pandemic lockdowns on health behaviors and quality of life among Chinese adults. Int. J. Environ. Res. Publ. Health, 17 (15), 5575

Whitaker, K. M., Hung, P., Alberg, A. J., Hair, N. L., Liu, J. (2021). Variations in health behaviors among pregnant women during the COVID-19 pandemic. Midwifery, 95, 102929.

WHO (1995). Physical status: The use and interpretation of anthropometry. Report of a WHO Expert Committee. WHO Tech. Rep. Ser., 854, 1-452.

Received 31 March 2021

Accepted in the final form 9 January 2022

\section{VESELĪBAS PARADUMU UN EMOCIONĀLĀS LABSAJŪTAS IZMAIN̦AS GRŪTNIECĒM COVID-19 PANDĒMIJAS LAIKĀ LATVIJĀ}

Grūtniecības laikā notiek pārmaiṇas gan fiziskajā, gan emocionālajā veselībā, kas sievietei palielina vairākus ar veselību saistītus riskus. COVID-19 pandēmija ir faktors, kas palielina ar grūtniecību saistītos riskus. Pētījuma mērkis bija izvērtēt COVID-19 ietekmi uz veselības paradumiem un emocionālo labsajūtu grūtniecēm Latvijā. Šḳērsgriezuma pētījumā tika iekḷautas 269 sievietes: grūtnieces trešajā grūtniecības trimestrī un sievietes līdz septītajai pēcdzemdību dienai. Pētījums norisinājās no 2020. gada jūlija līdz oktobrim. Aptauju veica apmācīts intervētājs. Tika ievākti demogrāfiskie, antropometriskie dati, kā arī COVID-19 pandēmijas izraisīto uztura paradumu, ikdienas fizisko aktivitāšu un emocionālās labsajūtas izmaiṇu pašvērtējums. Gandrīz trešdaḷa (31,6\%) ziṇoja, ka biežāk gatavo ēst mājās un tikai 10,4\% ziṇoja, ka ēd biežāk un/vai lielākās porcijās, 23,2\% biežāk devās pastaigāties svaigā gaisā. Gandrīz trešdaḷa $(32,9 \%)$ izjuta trauksmi, nedrošību par savu un tuvinieku veselību, gandrīz ceturtdaḷai $(24,8 \%)$ pietrūka komunikācijas ar tuviniekiem, draugiem. Latvietes šīs izmainas ietekmēja vairāk nekā citu tautību sievietes $(p=0,015)$. Kopumā sievietes vecumā 30+ gadi COVID-19 pandēmija ietekmēja biežāk nekā sievietes līdz 30 gadu vecumam $(p=0,014)$. Rezultāti parāda, ka COVID-19 pandēmija vērā ņemami ietekmē veselības paradumus un emocionālo labsajūtu grūtniecības laikā, īpaši sievietēm 30+ gadu vecumā, kurām būtu nepieciešams pievērst papildu uzmanību. 